\title{
PENGARUH METODE KOOPERATIF JIGSAW TERHADAP PRESTASI BELAJAR MATA PELAJARAN IPS PADA SISWA KELAS III
}

\author{
Maya Kartika Sari*
}

\begin{abstract}
This study aims to determine the effect of the use of cooperative learning of jigsaw method in social studies on student achievement of class III SD Pakualaman Bantul and SD Gandok Islamiyah in 2014/2015 school year. This research design uses quantitative research methods. Collecting data in this study uses the test method. The used test methods in this research are the pre-test and post-test given to the experimental group and the control group. While the data analysis is a statistical method t test ( $t$-test).

The results of data analysis $t$ test ( $t$-test) obtained value $=3.34$. At the significance level $(\alpha)=0.05$ and with $d b=38$ obtained value $=1.6859$. So that is $3.34 \geq 1.6859$, therefore $H o$ is rejected $H_{1}$ accepted. The conclusion of this study is that there is an effect on the use of cooperative learning of jigsaw model in social studies on student achievement of class III SD Islamiyah Pakualaman at school year 2014/2015.
\end{abstract}

Keywords: Cooperative Model Jigsaw Type, Learning Achievement

\begin{abstract}
Abstrak
Penelitian ini bertujuan untuk mengetahui pengaruh penggunaan metode pembelajaran kooperatif tipe jigsaw pada mata pelajaran IPS terhadap prestasi belajar siswa kelas III SD Islamiyah Pakualaman dan SD Gandok Bantul tahun pelajaran 2014/2015. Desain penelitian ini menggunakan metode penelitian kuantitatif. Pengumpulan data pada penelitian ini menggunakan metode tes. Metode tes yang digunakan yaitu pre test dan post test yang diberikan kepada kelompok eksperimen dan kelompok kontrol. Analisis data yang digunakan adalah metode statistik $\mathrm{t}$ test (uji-t).

Hasil analisis data $t$ test (uji-t) diperoleh nilai $=3,34$. Pada taraf signifikansi $(\alpha)=0,05$ dan dengan $\mathrm{db}=38$ diperoleh nilai $=1,6859$. Maka $\geq$ yaitu $3,34 \geq 1,6859$, maka Ho ditolak. $\mathrm{H}_{1}$ diterima. Kesimpulan dari hasil penelitian ini adalah ada pengaruh penggunaan model pembelajaran kooperatif tipe jigsaw pada mata pelajaran IPS terhadap prestasi belajar siswa kelas III SD Islamiyah Pakualaman tahun pelajaran 2014/2015.
\end{abstract}

Kata Kunci: Model Kooperatif Tipe Jigsaw, Prestasi Belajar

* Maya Kartika Sari adalah Dosen Prodi PGSD FIP IKIP PGRI MADIUN 


\section{A. Pendahuluan}

Pembelajaran Kooperatif merupakan metode pembelajaran yang mampu mengaktifkan siswa dalam pembelajaran. Hal ini dikarenakan siswa terbagi menjadi beberapa kelompok kecil dan saling bekerjasama untuk mengkaji dan memecahkan permasalahan yang diberikan oleh guru. Metode kooperatif memiliki berbagai tipe dalam pelaksanaannya, salah satunya yakni metode jigsaw. Pembelajaran kooperatif jigsaw merupakan salah satu tipe pembelajaran kooperatif yang mendorong siswa aktif dan saling membantu dalam menguasai materi pelajaran untuk mencapai prestasi yang maksimal

Metode jigsaw sangat baik diterapkan dalam pembelajaran dikarenakan melalui metode ini siswa menjadi lebih mandiri dalam belajar, artinya siswa belajar dengan siswa, dan guru sebagai fasilitator dalam pembelajaran. Siswa dalam membelajarkan siswa lain, dengan begitu harapannya siswa menjadi lebih paham dalam mengkaji materi karena gaya bahasa dan komunikasi dilakukan oleh teman mereka sendiri.

Pembelajaran dengan metode jigsaw diharapkan dapat memberikan pengaruh yang baik bagi siswa pada khususnya. Sebab, metode kooperatif tipe jigsaw ini pembelajarannya berpusat pada siswa yaitu dengan melibatkan siswa secara aktif untuk meningkatkan kualitas belajar dan prestasi terutama pada mata pelajaran IPS. Hal ini dikarenakan pembelajaran IPS merupakan mata pelajaran yang teoritis, bersifat hafalan dan bersifat monoton karena beberapa guru yang hanya mengajar dengan berceramah, konvensional, dan kurang mengaktifkan siswa dalam pembelajaran. Siswa cenderung dijejali dengan sejumlah konsep abstrak yang harus dihafalkan dan siswa tidak diberi kesempatan yang luas untuk mengonstruksi konsep yang abstrak itu melalui aktivitas yang nyata yang sebenarnya dialami sehari-hari. Permasalahan ini terjadi dibeberapa sekolah dasar termasuk di SD Islamiyah Pakualaman dan SD Gandok Bantul. Berdasarkan wawancara dan observasi awal yang dilakukan oleh peneliti ternyata di sekolah tersebut pada mata pelajaran IPS masih bersifat konvensional dan monoton, dan kurangnya variasi dalam penggunaan metode pembelajaran. Hal ini berakibat kurang berminat dan termotivasinya siswa dalam pembelajaran IPS sehingga prestasi belajar siswa menjadi kurang maksimal. Berdasarkan hasil pengamatan permasalahan tersebut, maka peneliti mencoba melaksanakan metode kooperatif tipe jigsaw dengan harapan pembelajaran di kelas III di SD Islamiyah Pakualaman dan SD Gandok Bantul menjadi lebih menyenangkan, berkualitas dan pada akhirnya dapat meningkatkan prestasi belajar siswa.

\section{B. Kajian Teori}

\section{Metode Pembelajaran Kooperatif tipe Jigsaw}

Metode pembelajaran Jigsaw adalah sebuah model belajar kooperatif yang menitikberatkan kepada kerja kelompok siswa dalam bentuk kelompok kecil, seperti yang diungkapkan Lie (1993: 73), bahwa metode pembelajaran Jigsaw ini merupakan model belajar kooperatif dengan cara siswa belajar dalam kelompok kecil yang terdiri atas empat sampai dengan enam orang secara heterogen dan siswa bekerja sama saling ketergantungan positif dan bertanggung jawab secara mandiri.

Metode pembelajaran kooperatif tipe Jigsaw berangkat dari dasar pemikiran getting better together yang menekankan pada pemberian kesempatan 
belajar yang lebih luas dan suasana yang kondusif pada siswa untuk memmperoleh dan mengembangkan pengetahuan, sikap dan nilai serta ketrampilan sosial yang bermanfaat dalam kehidupan masyarakat. Sehingga metode kooperatif tipe Jigsaw ini memiliki beberapa manfaat diantaranya yaitu merangsang dan mengembangkan potensi dan keaktifan siswa secara optimal dalam suasana belajar pada kelompok-kelompok kecil yang memiliki permasalahan yang berbeda dan siswa lebih mudah memahami pelajaran.

Metode kooperatif tipe Jigsaw mempunyai langkah-langkah dalam pembelajaran yakni sebagai berikut :

a. Siswa dikelompokan sebanyak 1 sampai dengan 5 orang siswa.

b. Tiap orang dalam tim diberi bagian materi berbeda

c. Tiap orang dalam tim diberi bagian materi yang ditugaskan

d. Anggota dari tim yang berbeda yang telah mempelajari bagian sub bagian yang sama bertemu dalam kelompok baru (kelompok ahli) untuk mendiskusikan sub bab mereka.

e. Setelah selesai diskusi sebagai tim ahli tiap anggota kembali ke dalam kelompok asli dan bergantian mengajar teman satu tim mereka tentang subbab yang mereka kuasai dan tiap anggota lainnya mendengarkan

f. Tiap tim ahli mempresentasikan hasil diskusi

g. Guru memberi evaluasi

h. Penutup

Secara garis besar, hubungan antara kelompok asal dan kelompok ahli tersebut digambarkan sebagai berikut:

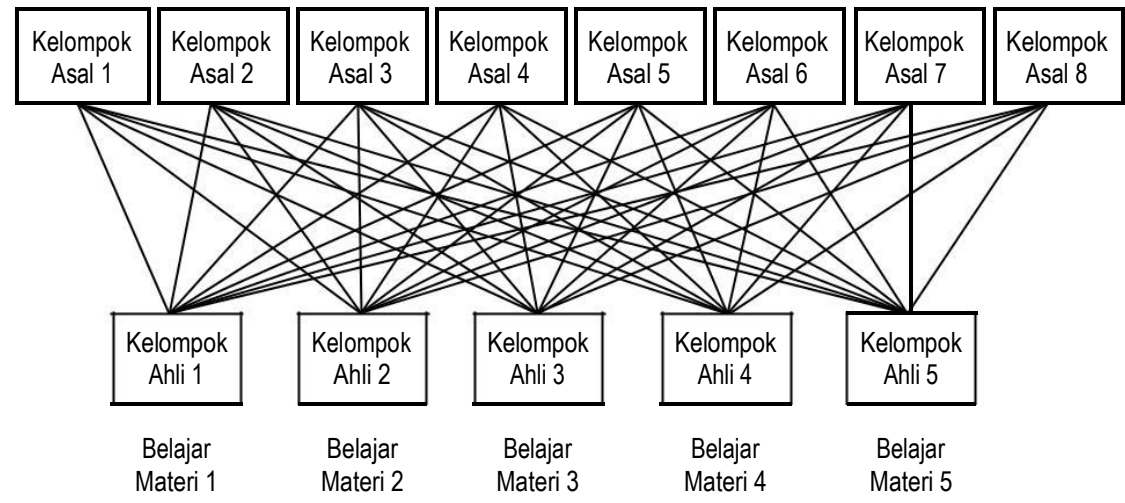

Teknik Jigsaw memiliki beberapa keunggulan dalam memberi kesempatan siswa untuk mengembangkan potensi diri. Beberapa keunggulan itu adalah:

a. Dapat menambah kepercayaan siswa akan kemampuan berpikir kritis.

b. Setiap siswa akan memiliki tanggung jawab akan tugasnya.

c. Mengembangkan kemampuan siswa mengungkapkan ide atau gagasan dalam memecahkan masalah

d. Dapat meningkatkan kemampuan sosial: mengembangkan rasa harga diri dan hubungan interpersonal yang positif.

e. Waktu pelajaran lebih efisien dan efektif.

f. Dapat berlatih berkomunikasi dengan baik.

Metode Jigsaw memiliki beberapa kelemahan jika dilihat dari beberapa aspek diantanya yaitu: 
a. Prinsip utama pembelajaran ini adalah "Peerteaching" yaitu pembelajaran oleh teman sendiri. Ini akan menjadi kendala karena persepsi dalam memahami suatu konsep yang akan didiskusikan bersama dengan siswa lain. Pengawasan guru menjadi hal mutlak diperlukan agar jangan sampai terjadi salah konsep (Miss Conception).

b. Dirasa sulit meyakinkan siswa untuk mampu berdiskusi menyampaikan materi pada teman, jika siswa tidak percaya diri, guru harus mampu memainkan perannya dalam memfasilitasi kegiatan belajar.

c. Rekod siswa tentang nilai, kepribadian, perhatian siswa harus sudah dimiliki oleh pendidik dan ini biasanya membutuhkan waktu yang cukup lama untuk mengenali tipe-tipe siswa dalam kelas tersebut.

d. Awal pembelajaran ini biasanya sulit dikendalikan, biasanya butuh waktu yang cukup dan persiapan yang matang sebelum model pembelajaran ini bias berjalan dengan baik.

\section{Pembelajaran IPS di Sekolah Dasar}

Menurut Syafruddin Nurdin (2005:22) "Ilmu Pengetahuan Sosial adalah salah satu mata pelajaran yang diajarkan di sekolah, mulai dari jenjang pendidikan dasar sampai ke pendidikan menengah". Menurut Arnie Fajar (2009: 110), "Pengetahuan sosial merupakan mata pelajaran yang mengkaji seperangkat peristiwa, fakta, konsep dan generalisasi yang berkaitan dengan isu sosial dan kewarganegaraan".

IPS sebagai satu program pendidikan tidak hanya menyajikan tentang konsep-konsep pengetahuan, tetapi juga membina siswa menjadi warga negara yang memahami hak dan kewajibannya, serta memiliki tanggung jawab atas kesejahteraan bersama yang seluas-luasnya. Proses pembelajaran pendidikan IPS dilakukan secara bertahap dan berkesinambungan sesuai dengan kebutuhan dan tingkat usia peserta didik masing-masing. Ragam pembelajarannya pun harus disesuaikan dengan apa yang terjadi dalam kehidupan. Secara formal, proses pembelajaran dan membelajarkan itu terjadi di sekolah, baik di dalam kelas maupun di luar kelas.

Pembelajaran IPS diharapkan mampu dikembangkan aspek pengetahuan dan pengertian (knowledge and understanding), aspek sikap dan nilai (atitude and value), dan aspek keterampilan (skill). Pembelajaran IPS berusaha membantu siswa dalam memecahkan permasalahan-permasalahan yang dihadapi, sehingga akan menjadikannya semakin mengerti dan memahami lingkungan sosial masyarakatnya.

Pola pembelajaran IPS di SD hendaknya lebih menekankan pada unsur pendidikan dan pembekalan pemahaman, nilai-moral, dan keterampilanketerampilan sosial pada siswa. Untuk itu, penekanan pembelajarannya bukan sebatas pada upaya mencekoki atau menjejali siswa dengan sejumlah konsep yang bersifat hapalan belaka, melainkan terletak pada upaya menjadikan siswa memiliki seperangkat pengetahuan, sikap, nilai, dan keterampilan agar mereka mampu menjadikan apa yang telah dipelajarinya sebagai bekal dalam memahami dan ikut serta dalam melakoni kehidupan masyarakat lingkungannya, serta sebagai bekal bagi dirinya untuk melanjutkan pendidikan ke jenjang yang lebih tinggi. Disinilah sebenarnya penekanan misi dari pembelajaran IPS di sekolah dasar. 
Rancangan pembelajaran guru, hendaknya diarahkan dan di fokuskan sesuai dengan kondisi dan perkembangan potensi siswa agar pembelajaran yang dilakukannya benar-benar berguna dan bermanfaat bagi siswa. Dengan demikian pembelajaran Pendidikan IPS semestinya diarahkan diarahkan pada upaya pengembangan iklim yang kondusif bagi siswa untuk belajar sekaligus melatih pengetahuan, sikap, nilai dan keterampilannya selama pembelajaran, disamping memungkinkan siswa untuk terlibat secara langsung dalam proses belajar mengajar.

\section{Prestasi Belajar}

Menurut Kamus Besar Bahasa Indonesia (2008: 1101) prestasi belajar adalah penguasaan pengetahuan atau keterampilan yang dikembangkan melalui mata pelajaran, lazimnya ditunjukkan dengan nilai tes atau nilai yang diberikan oleh guru. Sedangkan menurut Slameto (2003:128), Prestasi belajar adalah pengetahuan mengenai tingkat kemampuan intelektual atau intelegensi siswa akan membantu pengajar menentukan apakah siswa mampu mengikuti pengajaran yang diberikan, serta meramal keberhasilan atau gagalnya siswa yang bersangkutan bila telah mengikuti pengajaran yang diberikan.

Prestasi dipengaruhi oleh berbagai macam faktor yang memberikan kontribusi bagi keberhasilan siswa mencapai prestasi belajar yang baik. Faktorfaktor tersebut menurut Merson U. Sangalang (Tulus Tu'u, 2004: 78) terdiri dari: kecerdasan, bakat, minat dan perhatian, motif, kesehatan, cara belajar, lingkungan keluarga, lingkungan pergaulan, sekolah, sarana pendukung sekolah.

Jadi keberhasilan siswa mencapai prestasi belajar yang baik dipengaruhi oleh tingkat kecerdasan yang baik, sesuai bakat yang dimiliki, ada minat dan perhatian yang tinggi dalam belajar, motivasi yang baik dalam belajar, cara belajar yang variatif yang dikembangkan guru. Suasana keluarga yang memberi dorongan anak untuk maju. Serta lingkungan sekolah yang tertib, teratur, disiplin, yang kondusif bagi kegiatan kompetisi siswa dalam pembelajaran.

\section{Metode Penelitian}

\section{Setting Penelitian}

Penelitian ini dilaksanakan di SD Islamiyah Pakualaman sebagai kelas eksperimen dan SD Gandok Bantul sebagai kelas kontrol. Waktu penelitian 2 bulan yakni pada bulan Juli 2014 sampai September 2014 dengan tahapan pengajuan proposal, pengumpulan data, pengolahan data dan pembuatan laporan akhir penelitian.

\section{Rancangan Penelitian}

\section{a. Metode Penelitian}

Ditinjau dari tujuan akhir yang akan dicapai oleh peneliti, penelitian ini termasuk penelitian eksperimen. Metode eksperimen berguna untuk mengetahui ada tidaknya, pengaruh metode pembelajaran kooperatif tipe jigsaw terhadap prestasi belajar siswa di kelas eksperimen. Penelitian yang digunakan adalah penelitian kuantitatif, dimana sebagai pembanding atau kelas kontrol menggunakan metode ceramah/konvensional.

\section{b. Desain Penelitian}

Desain penelitian menggunakan Pre-Test-Post-Test Control Group Design. Dimana terdapat dua kelompok yaitu kelompok eksperimen dan kelompok kontrol atau pembanding. Kelompok pertama diberi perlakuan (X) yang 
disebut kelompok eksperimen dan kelompok yang lain tidak diberi perlakuan yang disebut kelompok pembanding atau kelompok kontrol. Kedua kelompok ini diberi pengukuran yang sama yaitu Pretest (tes sebelum pembelajaran) dan Posttest (tes setelah pembelajaran).

\section{c. Variabel Penelitian}

Dalam penelitian ini terdapat dua variabel yaitu variabel bebas dan variabel terikat. Variabel bebas dalam penelitian ini adalah metode pembelajaran kooperatif tipe jigsaw. Sedangkan Variabel terikat dalam penelitian ini adalah prestasi belajar siswa kelas III pada mata pelajaran IPS.

\section{Data dan cara pengumpulan \\ data a. Sumber dan jenis data}

Sumber data dari penelitian ini adalah siswa kelas III di SD Islamiyah Pakualaman dan SD Gandok Bantul. Dari keseluruhan populasi kelas III di SD Islamiyah Pakualaman dan SD Gandok Bantul, maka dalam penelitian ini menggunakan sampel kuota, yakni mengambil jumlah sampel yang diinginkan oleh peneliti. Peneliti ingin mengambil 20 sampel siswa dari SD Islamiyah Pakualaman dan 20 sampel SD Gandok Bantul.

Jenis data pada penelitian ini adalah data kuantitatif, yakni peneliti melakukan pengukuran menggunakan angka kemudian mendeskripsikan hasil penelitian yang telah didapatkan.

\section{b. Teknik pengambilan data}

Metode pengumpulan data yang digunakan dalam penelitian ini adalah teknik tes. Tes yang digunakan adalah pretest dan posttest yang diberlakukan sama antara kelas kontrol dan kelas eksperimen, namun dengan metode yang berbeda.

Tes yang digunakan dalam penelitian ini telah dilakukan uji validitas dan reliabelitas terhadap soal yang akan diberikan kepada siswa. Berdasarkan hasil uji validitas yang dilakukan terhadap instrumen tes yakni terdapat 24 soal yang valid sehingga peneliti menggunakan 20 soal untuk diberikan kepada siswa, sedangkan hasil reliabelitas instrumen tes diperoleh nilai $>$ yaitu $0,937>0,576$, maka tes dikatakan reliabel. Ini berarti instrumen tes prestasi tersebut reliabel, sehingga dapat digunakan untuk mengetahui tingkat prestasi siswa.

\section{c. Teknik Analisa Data}

Data dalam penelitan ini melalui uji normalitas dan uji homogenitas. Uji normalitas menggunakan rumus $\mathrm{Uji}$ Chi Kuadrat, dan uji homogenitas menggunakan uji $\mathrm{F}$. Tujuan untuk mengetahui pengaruh penggunaan metode pembelajaran jigsaw terhadap prestasi belajar siswa kelas III pada mata pelajaran IPS di SD Islamiyah Pakualaman dan SD Gandok Bantul. Data ini bersifat data interval. Rumus " $\mathrm{t}$ " test yang digunakan adalah:

$$
\mathrm{t}=\frac{\mathrm{x}_{1}-\mathrm{x}_{2}}{\mathrm{~S}_{\mathrm{gab}} \frac{\overline{\frac{1}{2}}+\frac{1}{\mathrm{n}_{1}}}{\mathrm{n}_{2}}}
$$

Langkah analisa data yang dilakukan peneliti yakni menulis $\mathrm{H}_{\mathrm{a}}$ dan $\mathrm{H}_{\mathrm{O}}$ dalam bentuk kalimat dan angka statistik, menghitung nilai $\mathrm{t}$ tes, menentukan taraf signifikan $\alpha=95 \%$ atau 99\%, mencari $t_{\text {tabel }}$ dengan pengujian dua pihak dimana 
$\mathrm{dk}=\mathrm{n}_{1}+\mathrm{n}_{2}-2$, menentukan kriteria pengujian yakni Ha diterima jika $\mathrm{t}_{\text {hitung }}>$

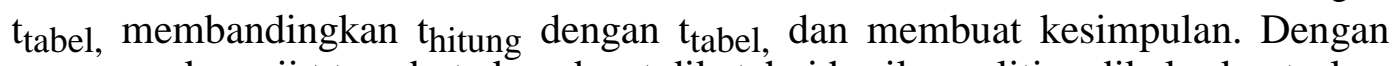
menggunakan uji t tersebut akan dapat diketahui hasil penelitian dikelas kontrol dan kelas eksperimen, sehingga peneliti dapat menyimpulkan hasil penelitian yang relevan.

\section{Hasil Penelitian dan}

\section{Pembahasan 1. Deskripsi Data}

Data yang disajikan pada penelitian ini adalah data tes yakni pretest dan posttest siswa kelas III SD Islamiyah Pakualaman setelah mendapat perlakuan dengan metode pembelajaran jigsaw dan SD Gandok Bantul setelah mendapat perlakuan dengan metode pembelajaran konvensional.

\section{a. Data Nilai Kelompok Eksperimen}

Data nilai kelompok eksperimen merupakan data yang diperoleh dari hasil belajar IPS siswa kelas III SD Islamiyah Pakualaman melalui pretest (sebelum proses pembelajaran) dan posttest (setelah proses pembelajaran dengan menggunakan metode jigsaw) pada 20 siswa. Adapun data nilai hasil pretest dan posttest adalah sebagai berikut.

\section{Tabel 1. Hasil Pretest dan Posttest Kelompok Eksperimen}

\begin{tabular}{clcc}
\hline Nomor & \multicolumn{1}{c}{ Nama Siswa } & Nilai Pretest & Nilai Posttest \\
\hline 1 & Danar Aufak & 80 & 100 \\
\hline 2 & Siti Muamanah & 55 & 95 \\
\hline 3 & Faisal Jatmiko & 65 & 90 \\
\hline 4 & Citra Virginia & 45 & 65 \\
\hline 5 & Tito Nurhadi & 60 & 80 \\
\hline 6 & Nopi Eka Nurhayati & 75 & 95 \\
\hline 7 & Shandy Darmawan & 60 & 80 \\
\hline 8 & Salsabila n. & 40 & 70 \\
\hline 9 & Indra Nur Arifin & 60 & 75 \\
\hline 10 & Andre Nur Arifin & 60 & 85 \\
\hline 11 & Reza Aprilian & 55 & 75 \\
\hline 12 & Rio Faiz & 45 & 85 \\
\hline 13 & Erna Widiani & 60 & 85 \\
\hline 14 & Delia Ardista & 60 & 95 \\
\hline 15 & Risma Sukma & 50 & 80 \\
\hline 16 & Keanu Jaypiar & 60 & 90 \\
\hline 17 & Intan Pratiwi & 75 & 90 \\
\hline 18 & Ayu Riana & 60 & 85 \\
\hline 19 & Ega Satriawan & 55 & 80 \\
\hline 20 & Rizki Ramadhan & 70 & 100 \\
\hline & Jumlah & 1190 & 1700 \\
\hline
\end{tabular}

Berdasarkan data yang dari nilai pretest dan posttest pada kelas ekperimen dengan SKM 65, diperoleh data nilai pretest dengan nilai terendah 40 dan nilai tertinggi 80 terdapat 15 siswa yang tidak tuntas dan 5 siswa yang tuntas dengan prosentase ketuntasan $25 \%$. Sedangkan nilai posttest memiliki nilai terendah 65 dan nilai tertinggi 100, semua siswa tuntas dalam posttest ini, sehingga mempunyai prosentase ketuntasan $100 \%$. Peningkatan nilai kelas eksperimen 
setelah diberi perlakuan dengan model jigsaw dari nilai pretest dan nilai posttest sebanyak $75 \%$.

\section{b. Data Nilai Kelompok Kontrol}

Data nilai kelompok kontrol merupakan data yang diperoleh dari hasil belajar IPS siswa kelas III SD Gandok Bantul melalui pretest (sebelum proses pembelajaran) dan posttest (setelah proses pembelajaran dengan menggunakan model konvensional) pada 20 siswa. Adapun data nilai hasil pretest dan posttest adalah sebagai berikut;

\section{Tabel 2. Hasil Pretest dan Posttest Kelompok Kontrol}

\begin{tabular}{clcc}
\hline Nomor & \multicolumn{1}{c}{ Nama Siswa } & Nilai Pretest & Nilai Posttest \\
\hline 1 & Dimas Prasetyo & 60 & 75 \\
\hline 2 & Sherly Eka & 65 & 70 \\
\hline 3 & Ragil Tegar & 45 & 65 \\
\hline 4 & Andrian Taufik & 35 & 70 \\
\hline 5 & Dika Dwi Setyadi & 60 & 75 \\
\hline 6 & Muhammad Wildan & 80 & 90 \\
\hline 7 & Nadila Meilan & 55 & 75 \\
\hline 8 & Hingki Fadhlan & 50 & 85 \\
\hline 9 & Tika Puspita & 45 & 70 \\
\hline 10 & Alifatul Anisa & 50 & 75 \\
\hline 11 & Ade Hendra & 60 & 70 \\
\hline 12 & Dimas Agung & 75 & 75 \\
\hline 13 & Deya Anjelina & 75 & 85 \\
\hline 14 & Wilda Rozika & 60 & 75 \\
\hline 15 & Muhammad Muklis & 60 & 80 \\
\hline 16 & Tyas Tera & 65 & 90 \\
\hline 17 & Wahyudha Yosa & 70 & 75 \\
\hline 18 & Galang Nirwana & 60 & 85 \\
\hline 19 & Fajri hadi & 75 & 80 \\
\hline 20 & Juniva Syahira & 60 & 1545 \\
\hline & Jumlah & 1205 & \\
\hline & & & \\
\hline
\end{tabular}

Berdasarkan data yang dari nilai pretest dan posttest pada kelas kontrol dengan SKM 65, diperoleh data nilai pretest dengan nilai terendah 35 dan nilai tertinggi 80 terdapat 13 siswa yang tidak tuntas dan 7 siswa yang tuntas dengan prosentase ketuntasan 35\%. Sedangkan nilai posttest memiliki nilai terendah 65 dan nilai tertinggi 90, semua siswa tuntas dalam posttest ini, sehingga mempunyai prosentase ketuntasan $100 \%$. Peningkatan nilai kelas kontrol setelah diberi perlakuan dengan metode konvensional dari nilai pretest dan nilai posttest sebanyak $65 \%$.

\section{c. Perhitungan Pretest dan Posttest Kelompok Eksperimen dan Kontrol}

Berdasarkan pengolahan data pretest dan posttest siswa kelas III pada mata pelajaran IPS dengan menggunakan metode pembelajaran tipe jigsaw (kelas eksperimen) dan menggunakan metode pembelajaran konvensional (kelas kontrol). Maka diperoleh hasil pengolahan data sebagai berikut: 
Tabel 3. Hasil Pengolahan Nilai Pretest dan Posttest

\begin{tabular}{lcccc}
\hline \multirow{2}{*}{ Hasil } & \multicolumn{2}{c}{ Kelas Eksperimen } & \multicolumn{2}{c}{ Kelas Kontrol } \\
\cline { 2 - 5 } & Pre-Test & Post-Test & Pre-Test & Post-Test \\
\hline $\mathrm{N}$ (jumlah siswa) & 20 & 20 & 20 & 20 \\
\hline $\mathrm{X}_{\text {maks }}$ (Skor maksimal) & 80 & 100 & 80 & 90 \\
\hline $\mathrm{X}_{\text {min }}$ (Skor minimal) & 40 & 65 & 35 & 65 \\
\hline (Rata - rata) & 58,70 & 85 & 59,25 & 77,25 \\
\hline $\mathrm{S}$ (simpangan baku) & 10,02 & 8,88 & 10,48 & 6,13 \\
\hline
\end{tabular}

Dari data diatas dapat dilihat bahwa siswa yang menggunakan metode pembelajaran jigsaw mempunyai nilai rata-rata pretest 58,70 dengan nilai maksimal 80 serta minimal 40 dan nilai rata-rata posttest 85 dengan nilai maksimal 100 serta nilai minimal 65. Prosentase peningkatan nilai kelas eksperimen dari nilai pretest dan nilai posttest sebanyak $75 \%$. Sedangkan siswa yang diajar dengan menggunakan model pembelajaran konvensional mempunyai nilai rata-rata pretest 59,25 dengan nilai maksimal 80 serta minimal 35 dan nilai rata-rata posttest 77,25 dengan nilai maksimal 90 serta nilai minimal 65 . Prosentase peningkatan nilai kelas kontrol dari nilai pretest dan nilai posttest sebanyak $65 \%$.

Berdasarkan pernyataan diatas, dapat disimpulkan bahwa rata-rata nilai tes IPS siswa kelas eksperimen lebih baik dibandingkan rata-rata nilai pada kelas kontrol. Prosentase kenaikan nilai pada kelas eksperimen antara pretest dan posttest setelah diberi perlakuan metode pembelajaran jigsaw lebih tinggi yaitu $75 \%$, sedangkan prosentase kenaikan nilai pada kelas kontrol antara pretest dan posttest setelah diberi perlakuan metode pembelajaran konvensional lebih rendah yaitu $65 \%$. Hal ini berarti hasil tes belajar pada kelas eksperimen yang menggunakan metode pembelajaran jigsaw lebih baik dibandingkan hasil tes belajar pada kelas kontrol yang hanya menggunakan metode pembelajaran konvensional.

\section{Analisa Data}

Analisis data dilakukan untuk menguji kebenaran hipotesis yang diajukan dalam penelitian ini yaitu ada pengaruh penggunaan metode pembelajaran kooperatif tipe jigsaw pada mata pelajaran IPS terhadap prestasi belajar siswa kelas III di SD Islamiyah Pakualaman dan SD Gandok Bantul tahun pelajaran 2014/2015. Untuk mengetahui kebenaran hipotesis ini maka penulis membandingkan hasil belajar belajar IPS siswa kelas eksprimen yang menggunakan metode pembelajaran tipe jigsaw dengan hasil belajar IPS kelas kontrol yang menggunakan metode pembelajaran konvensional. Sebelum membuktikan hipotesis, langkah-langkah yang terlebih dahulu dilakukan adalah melakukan uji normalitas dan uji homogenitas.

\section{a. Analisa data pretest}

\section{1) Uji Normalitas}

Uji normalitas dilakukan untuk mengetahui apakah sampel berdistribusi normal atau tidak. Uji normalitas yang digunakan peneliti dalam penelitian ini 
dengan menggunakan Chi Kuadrat. Data sampel dikatakan berdistribusi normal apabila Chi Kuadrat Hitung $\left(\mathrm{X}_{\mathrm{h}}{ }^{2}\right) \leq$ Chi Kuadrat Tabel $\left(\mathrm{X}_{\mathrm{t}}^{2}\right)$ dan apabila Chi Kuadrat Hitung $\left(\mathrm{X}_{\mathrm{h}}{ }^{2}\right) \geq \mathrm{Chi}$ Kuadrat Tabel $\left(\mathrm{X}_{\mathrm{t}}^{2}\right)$ maka data sampel dikatakan tidak berdistribusi normal. Berikut ini adalah hasil dari uji normalitas pada kelas kontrol dan kelas eksperimen.

Tabel 4. Hasil Perhitungan pretest Normalitas dengan Chi Kuadrat

\begin{tabular}{cccccc}
\hline No & \multirow{2}{*}{ Kelas } & $\begin{array}{c}\text { Chi Kuadrat } \\
\text { Hitung }\left(\mathrm{X}_{\mathrm{h}}{ }^{2}\right)\end{array}$ & $\begin{array}{c}\text { Chi Kuadrat } \\
\text { Tabel }\left(\mathrm{X}_{\mathrm{t}}{ }^{2}\right)\end{array}$ & Kesimpulan & Keterangan \\
\hline 1 & Eksperimen & 3,28 & 5,591 & $\left(\mathrm{X}_{\mathrm{h}}{ }^{2}\right) \leq\left(\mathrm{X}_{\mathrm{t}}{ }^{2}\right)$ & Sampel Normal \\
2 & Kontrol & 5,27 & 5,591 & $\left(\mathrm{X}_{\mathrm{h}}{ }^{2}\right) \leq\left(\mathrm{X}_{\mathrm{t}}{ }^{2}\right)$ & Sampel Normal \\
\hline
\end{tabular}

Berdasarkan perhitungan nilai pretes pada tabel diatas, diperoleh nilai Chi Kuadrat Hitung yaitu 3,28. Nilai tersebut kemudian dibandingkan dengan nilai Chi Kuadrat Tabel dengan db (derajat kebebasan) $=\mathrm{k}-3=5-3=2$ dan taraf signifikansi 5\%, maka nilai Chi Kuadrat Tabel yaitu 5,591. Karena nilai $\mathrm{x}^{2}$ hitung $\leq \mathrm{x}^{2}$ tabel yaitu $3,28 \leq 5,591$, maka sampel pada kelas eksperimen berdistribusi normal.

Sedangkan hasil perhitungan pretes yang telah dilakukan dikelas kontrol, diperoleh nilai Chi Kuadrat Hitung yaitu 5,27. Nilai tersebut kemudian dibandingkan dengan nilai Chi Kuadrat Tabel dengan db (derajat kebebasan) $=\mathrm{k}-3=5-3=2$ dan taraf signifikansi 5\%, maka nilai Chi Kuadrat Tabel yaitu 5,591. Karena nilai $x^{2}$ hitung $\leq \mathrm{x}^{2}$ tabel yaitu 5,27 $\leq 5,591$, maka sampel berdistribusi normal

\section{2) Uji Homogenitas}

Setelah uji normalitas dilakukan selanjutnya menghitung uji homogenitas. Uji homogenitas dilakukan untuk mengetahui sampel yang ada sudah homogen atau tidak homogen. Untuk mengetahui homogenitas sampel dengan pretes, menggunakan rumus Uji F. Data sampel dikatakan bersifat homogen apabila $\leq$ dan apabila $\geq$ maka data sampel dikatakan tidak homogen. Berikut ini adalah hasil dari uji normalitas pada kelas kontrol dan kelas eksperimen.

Berdasarkan perhitungan nilai pretes yang telah dilakukan, diperoleh nilai adalah 1,09. Pada taraf signifikansi $(\alpha)=0,05$ dengan $\mathrm{db}=(19,19)$ diperoleh harga adalah 2,17 . Oleh karena nilai $\leq$ yaitu $1,09 \leq 2,17$, maka kedua sampel yang digunakan bersifat homogen.

\section{b. Analisa data posttest}

\section{1) Uji Normalitas}

Uji normalitas yang digunakan peneliti dalam penelitian ini dengan menggunakan Chi Kuadrat. Berikut ini adalah hasil dari uji normalitas pada kelas kontrol dan kelas eksperimen.

Tabel 5. Hasil Perhitungan Posttest Normalitas dengan Chi Kuadrat

\begin{tabular}{cccccc}
\hline No & \multirow{2}{*}{ Kelas } & $\begin{array}{c}\text { Chi Kuadrat } \\
\text { Hitung }\left(\mathrm{X}_{\mathrm{h}}{ }^{2}\right)\end{array}$ & $\begin{array}{c}\text { Chi Kuadrat } \\
\text { Tabel }\left(\mathrm{X}_{\mathrm{t}}{ }^{2}\right)\end{array}$ & Kesimpulan & Keterangan \\
\hline 1 & Eksperimen & 3,53 & 5,591 & $\left(\mathrm{X}_{\mathrm{h}}{ }^{2}\right) \leq\left(\mathrm{X}_{\mathrm{t}}{ }^{2}\right)$ & Sampel Normal \\
\hline 2 & Kontrol & 4,36 & 5,591 & $\left(\mathrm{X}_{\mathrm{h}}{ }^{2}\right) \leq\left(\mathrm{X}_{\mathrm{t}}{ }^{2}\right)$ & Sampel Normal \\
\hline
\end{tabular}


Berdasarkan perhitungan posttest yang telah dilakukan, di kelas eksperimen di SD Islamiyah Pakualaman diperoleh nilai Chi Kuadrat Hitung yaitu 3,53. Nilai tersebut kemudian dibandingkan dengan nilai Chi Kuadrat Tabel dengan $\mathrm{db}$ (derajat kebebasan) $=\mathrm{k}-3=5-3=2$ dan taraf signifikansi 5\%, maka nilai Chi Kuadrat Tabel yaitu 5,591. Karena nilai $\mathrm{x}^{2}$ hitung $\leq \mathrm{x}^{2}$ tabel yaitu 3,35 5,591, maka sampel berdistribusi normal.

Sedangkan di SD Gandok sebagai kelas kontrol diperoleh nilai Chi Kuadrat Hitung yaitu 4,36. Nilai tersebut kemudian dibandingkan dengan nilai Chi Kuadrat Tabel dengan db (derajat kebebasan) $=\mathrm{k}-3=5-3=2$ dan $\operatorname{taraf}_{2}$ signifikansi 5\%, maka nilai Chi Kuadrat Tabel yaitu 5,591. Karena nilai $x^{2}$ hitung $\leq \mathrm{x}^{2}$ tabel yaitu 4,36 $\leq 5,591$, maka sampel berdistribusi normal.

\section{2) Uji Homogenitas}

Setelah uji normalitas dilakukan selanjutnya menghitung uji homogenitas. Setelah perhitungan yang telah dilakukan, diperoleh nilai adalah 2,10. Pada taraf signifikansi $(\alpha)=0,05$ dengan $d b=(19,19)$ diperoleh harga adalah 2,17 . Oleh karena nilai $\leq$ yaitu $2,10 \leq 2,17$, maka kedua sampel yang digunakan bersifat homogen.

\section{Hasil Pengujian Hipotesis}

Setelah uji normalitas dan uji homogenitas dilakukan, dapat disimpulkan bahwa kedua sampel yang digunakan berdistribusi normal dan bersifat homogen. Oleh karena itu, untuk mengetahui ada tidaknya pengaruh penggunaan metode pembelajaran kooperatif tipe jigsaw pada mata pelajaran IPS terhadap prestasi belajar siswa kelas III di SD Islamiyah Pakualaman dan SD Gandok Bantul tahun pelajaran 2014/2015 dapat dilakukan dengan menggunakan Uji t. Setelah dilakukan perhitungan $t$ test, diperoleh nilai adalah 3,34. Pada taraf signifikansi $(\alpha)=0,05$ dan dengan $=20+20-2=38$, maka diperoleh nilai adalah 1,6859. Oleh karena nilai $\geq$ yaitu $3,34 \geq 1,6859$, maka Ho ditolak.

Berdasarkan hasil analisis data yang telah dilakukan, diperoleh nilai $\geq$ yaitu 3,34 $\geq 1,6859$, maka Ho ditolak. Maka peneliti menyimpulkan bahwa ada pengaruh penggunaan metode pembelajaran kooperatif tipe jigsaw pada mata pelajaran IPS terhadap prestasi belajar siswa kelas III di SD Islamiyah Pakualaman tahun pelajaran 2014/2015.

\section{Pembahasan}

Dalam penelitian eksperimen ini, pembelajaran terhadap kedua kelompok dilakukan dengan cara yang berbeda. Kelompok pertama sebagai kelas eksperimen menggunakan metode pembelajaran tipe jigsaw sedangkan kelompok kedua sebagai kelas kontrol menggunakan metode pembelajaran konvensional. Untuk mengetahui tingkat penguasaan siswa terhadap materi pelajaran yang dalam pembelajaran dilakukan dengan cara yang berbeda, peneliti mengukurnya melalui hasil tes belajar siswa. Tes yang dilakukan ini sebanyak dua kali yaitu yang disebut pretest (tes sebelum proses pembelajaran) dan posttest (tes setelah proses pembelajaran).

Pretest digunakan untuk mengetahui kemampuan awal siswa sebelum dilakukan pembelajaran, dari data nilai pretest dihitung dengan uji normalitas dan uji homogenitas. Data yang diperoleh menunjukkan bahwa data berdistribusi normal dan bersifat homogen. Kemudian pembelajaran dilakukan pada masing- 
masing kelompok. Pembelajaran di kelas eksperimen mendapat perlakuan dengan menggunakan metode pembelajaran jigsaw. Saat dijelaskan pertama kali tentang metode pembelajaran dengan jigsaw, siswa merasa kebingungan bagaimana metode itu dilakukan pada saat pembelajaran. Akan tetapi setelah diberi penjelasan yang kedua, siswa sudah mengerti bagaimana pembelajaran yang akan mereka lakukan nanti.

Saat pembelajaran siswa merasa sangat senang dan semangat, karena mereka akan mempelajarinya dengan teman-teman kelompoknya dan kelompok lain yang disebut kelompok ahli. Dalam pembelajaran jigsaw masing-masing siswa diberi kepercayaan untuk menjadi perwakilan kelompok untuk berdiskusi memahami materi yang akan disampaikan kepada temannya. Karena masingmasing siswa menjadi perwakilan kelompok, mereka merasa senang bahwa dirinya mendapat kepercayaan dari kelompoknya untuk menguasai meteri dan menjelaskan kembali kepada temannya.

Selain itu pembelajaran yang dilakukan tidak sepenuhnya berasal dari informasi pengajar saja, pengajar hanya memfasilitasi saja. Materi pelajaran yang akan dipelajari dan dikuasai siswa, mereka cari informasinya dengan teman kelompoknya. Jadi mereka menggali pengetahuannya sendiri bersama teman kelompoknya, sehingga apa yang mereka pelajari dapat dimengerti oleh siswa sendiri dan materi tersebut dapat dikuasai siswa dengan baik. Dari materi yang masing-masing siswa pelajari dan dari materi lain yang diinformasi teman, pada akhirnya mereka dapat menguasai materi sepenuhnya dengan baik. Penguasaan materi yang dimiliki siswa ini terbukti dari hasil tes masing-masing siswa pada akhir pelajaran yang memuaskan.

Sedangkan pembelajaran yang dilakukan pada kelompok kontrol dengan menggunakan metode pembelajaran konvensional, penyampaian materi sepenuhnya berasal dari penjelasan guru dan siswa hanya mendengarkan penjelasan tersebut. Guru dalam pembelajaran banyak menggunakan ceramah, hal ini tidak menarik perhatian siswa dan kurang efektif dalam pembelajaran. Siswa kurang antusias dalam mempelajari materi tersebut, hanya terlihat siswa yang pandai saja yang terlihat aktif. Pada akhir pembelajaran juga diberi tes akhir seperti pada kelas eksperimen, akan tetapi hasil yang didapat oleh kelas kontrol tidak begitu memuaskan dan hanya siswa yang pandai saja yang mendapat nilai yang baik.

Tes akhir yang diberikan kepada kedua kelompok setelah pembelajaran dinamakan posttest. Tes setelah pembelajaran ini dilakukan untuk mengetahui seberapa besar pemahaman siswa terhadap materi pelajaran yang diberikan kepada masing-masing kelompok dengan model yang berbeda. Perhitungan hasil nilai pretest dan posttest diperoleh dari kelas eksperimen maupun kelas kontrol. Untuk kelas eksperimen dengan jumlah siswa 20 dan SKM 65 memiliki nilai pretest terendah 40 dan nilai tertinggi 80 dengan rata-rata nilai 58,70. Sedangkan nilai posttest terendah 65 dan nilai tertinggi 100 dengan rata-rata nilai 85 yang memiliki prosentase kenaikan nilai sebesar $75 \%$ setelah diberi perlakuan dengan metode pembelajaran tipe jigsaw.

Sedangan pada kelas kontrol dengan jumlah siswa 20 dan SKM 65 memiliki nilai pretest terendah 35 dan nilai tertinggi 80 dengan rata-rata nilai 59,25 . Sedangkan nilai posttest terendah 65 dan nilai tertinggi 90 dengan rata-rata 
nilai 77,25 yang memiliki prosentase kenaikan nilai sebesar $65 \%$ setelah diberi perlakuan dengan metode pembelajaran konvensional.

Dari paparan diatas, pembelajaran yang menggunakan metode pembelajaran jigsaw lebih efektif dibandingkan dengan pembelajaran menggunakan metode konvensional. Terbukti dari hasil tes belajar siswa pada mata pelajaran IPS, siswa kelas eksperimen yang menggunakan metode pembelajaran jigsaw memiliki peningkatan prosentase nilai yang lebih besar dan rata-rata nilai kelas yang lebih tinggi dibanding dengan nilai siswa kelas kontrol yang menggunakan metode pembelajaran konvensional.

Data nilai posttest dari kedua kelompok diperoleh bahwa data berdistribusi normal dan bersifat homogen, hal ini berarti data dapat dilakukan perhitungan hipotesis dengan menggunakan uji t. Hasil perhitungan hipotesis pada taraf signifikansi $(\alpha)=0,05$ dan dengan $=20+20-2=38$ diperoleh nilai $\geq$ yaitu 3,34 $\geq 1,6859$, maka Ho ditolak dan Ha diterima. Dari kesimpulan tersebut berarti hipotesis penelitian diterima yaitu ada pengaruh penggunaan metode pembelajaran kooperatif tipe jigsaw pada mata pelajaran IPS terhadap prestasi belajar siswa kelas III di SD Islamiyah Pakualaman tahun pelajaran 2014/2015.

\section{E. Penutup}

Dari analisis data dan pembahasan yang telah disampaikan dapat disimpulkan sebagai berikut:

a. Ada perbedaan prestasi belajar siswa dengan menggunakan metode pembelajaran kooperatif tipe jigsaw dan metode pembelajaran konvensional dalam pembelajaran pada mata pelajaran IPS kelas III di SD Islamiyah Pakualaman dan SD Gandok Bantul tahun pelajaran 2014/2015. Hal ini dapat dilihat dari prosentase kenaikan nilai pada kelas eksperimen (SD Islamiyah Pakualaman) yang lebih baik yaitu sebesar 75\%, sedangkan prosentase kenaikan nilai pada kelas kontrol (SD Gandok Bantul) sebesar $65 \%$.

b. Berdasarkan perhitungan $\mathrm{t}$ test, diperoleh nilai adalah 3,34. Pada taraf signifikansi $(\alpha)=0,05$ dan dengan $=20+20-2=38$, maka diperoleh nilai adalah 1,6859. Oleh karena nilai $\geq$ yaitu 3,34 $\geq 1,6859$, maka Ho ditolak. Maka ada pengaruh penggunaan metode pembelajaran kooperatif tipe jigsaw pada mata pelajaran IPS terhadap prestasi belajar siswa kelas III di SD Islamiyah Pakualaman tahun pelajaran 2014/2015. 


\section{DAFTAR PUSTAKA}

Agus Supijono. 2011. Cooperative Learning Teori dan Aplikasi PAIKEM. Yogyakarta: Pustaka Pelajar.

Dimyati dan Mujiono. 2002. Belajar dan Pembelajaran. Jakarta. Rineka Cipta.

Etin Solihatin dan Raharjo. 2007. Cooperative Analisis Model Pembelajaran IPS. Jakarta: Bumi Aksara.

Hamid Darmadi. 2010. Kemampuan Dasar Mengajar. Bandung: Alfabeta.

Ischak SU. 2001. Pendidikan IPS di SD. Jakarta: Universitas Terbuka.

Isjoni. 2010. Cooperative Learning Mengembangkan Kemampuan Belajar Kelompok. Bandung: Alfabeta.

Maya Kartika. 2014. Pembelajaran IPS di Sekolah Dasar Sesuai Kurikulum 2013. Madiun: IKIP PGRI Madiun.

Rusman. 2011. Model-Model Pembelajaran yang Mengembangkan Keprofesionalisme Guru. Jakarta: PT. Raja Grafindo Persada.

Sapriya. 2009. Pendidikan IPS Konsep dan Pembelajaran . Bandung Rosdakarya.

Slameto. 2003. Belajar dan Faktor-Faktor yang Mempengaruhinya. Jakarta: Rineka Cipta.

Sugiyono. 2007. Metode Penelitian Kuantitatif, Kualitatif dan R\&D. Bandung: Alfabeta.

Suharsimi Arikunto. 2010. Prosedur Penelitian Suatu Pendekatan Praktik. Jakarta: Rineka Cipta.

Syafruddin Nurdin. 2005. Model Pembelajaran Yang Memperhatikan Keragaman Individu Siswa dalam Kurikulum Bebasis Kompetensi. Jakarta:Quantum Teaching.

Tulus Tu'u. 2004. Peran Disiplin pada Perilaku dan Prestasi Siswa. Jakarta: Gramedia Widiasarana Indonesia. 